\title{
ANALYSIS OF THE EU TERRITORIAL DIFFERENCES IN TERMS OF NATURAL CONDITIONS WITH SPECIAL VIEW OF CZECH NUTS 2 REGIONS
}

\author{
Tomáš Hlavsa ${ }^{1}$, Andrea Čapkovičová ${ }^{2}$
}

Received 13 February 2012; Accepted 12 April 2013

\begin{abstract}
This paper analyses differences and similarities between the NUTS 2 regions of the European Union in terms of natural conditions with the subsequent evaluation of differences in land use, size structure, enterprise focus and selected economic indicators. The paper is also focused on the evaluation of the position of regions of the Czech Republic. NUTS 2 EU regions were classified into four groups, where the first represented favorable conditions for agriculture, on the other side the other group with conditions unsuitable for intensive agriculture - mountainous areas and the last two groups represented a transition between them. Czech regions were found in all groups except mountainous areas. Based on the analysis can we say that between clusters were found significant differences in the structure of farms, size of the enterprises, business focus but differences were not found in the economic indicators.
\end{abstract}

Key words: region, EU, natural condition, land use, farm structure, cluster analysis, ANOVA.

Souhrn: Článek se zabývá analýzou rozdílností a podobností mezi EU regiony typu NUTS 2 z pohledu prírodních podmínek, dále pak hodnocení rozdílů ve využití půdy, velikostní struktuře, zaměřením podniku a ve vybraných ekonomických ukazatelích. Článek je rovněž zaměřen na zhodnocení pozice regionů České republiky. Regiony NUTS 2 byly rozčleněny do čtyř skupin, kde jedna skupina reprezentovala príznivé podmínky pro zemědělství, na straně druhé shluk regionů s podmínky pro intenzivní zemědělství nevhodnými. Zbylé dvě skupiny představovaly přechod mezi vhodnými a nevhodnými podmínkami. Regiony ČR byly ve všech skupinách vyjma skupiny nevhodné pro intenzivní zemědělství, reprezentující horské oblasti. Na základě další analýze Ize konstatovat, že mezi skupinami regionů byly nalezeny významné rozdíly ve faremní struktuře, velikostní skupině podniků, zaměřením podniků. Nebyly však nalezeny rozdíly v ekonomických ukazatelích.

Klíčová slova: region, EU, přírodní podmínky, užití půdy, faremní struktura, shluková analýza, ANOVA.

\footnotetext{
${ }^{1}$ Ing. Tomáš Hlavsa, Ph.D., Institute of Agricultural Economics and Information Prague, Mánesova 75, 12056 Praha 2, Czech Republic; E-mail address: hlavsa.tomas@uzei.cz

2 Andrea Čapkovičová, MSc., Institute of Agricultural Economics and Information Prague, Mánesova 75, 12056 Praha 2, Czech Republic, E-mail address: capkovicova.andrea@uzei.cz
} 


\section{Introduction}

After the year 2013 starts the new programming period, and within this period there are planned changes in the Common Agricultural Policy (CAP). On the one hand, it is considered to unify conditions for providing payments to all EU member states; such as the ceiling for direct payments, on the other hand it is to support other regional specificities of the agricultural and rural development. Differences in natural conditions for farming are evident both at the national level and at the regional level across the whole EU. The natural and economic dispersions are discussed for example in Wilkin (2003). The differences between these regions may be in certain cases very big; this could contradict the unification of CAP instruments. Disunity of the less favoured areas (LFA) definition in the EU was also criticised in the past (Crabtree, et al, 2003a, 2003b). The disunity of LFA and natural conditions definition is also precisely elaborated in Cooper, et al (2006). Regional conditioning of subsidies is in general highly debated issue in regional and rural development, (e.g. Boháčková, Hrabánková 2010). Agricultural subsidies are paid for hectares of agricultural land, for production or they are regionally targeted, this may include for example support for the LFA. Targeting the subsidies, especially the LFA, is then determined by regional differences and natural conditions. The objective of the new CAP after 2013 (Copa \& Cogeca 2011; EC, 2011) ensure that all production is carried out in a way which protects the environment (air, soil, water), protects animal welfare and biodiversity and provides an attractive countryside. The new CAP encourages land management practices which promote biodiversity, resource and habitat conservation, taking into account specific regional conditions. These facts have become the incentive for the analysis of territorial differences in terms of natural conditions.

\section{Goal}

The aim is to evaluate the differences and similarities between the NUTS 2 regions of the European Union in terms of natural conditions with special view on agricultural disadvantages. The subsequent evaluation will be focused on differences in land use, size structure, enterprise focus and economic indicators. The partial aim is to evaluate the position of regions of the Czech Republic in the context of the European Union in terms of given indicators.

\section{Material and Methods}

In the light of the importance of future challenges for food security, the environment and territorial balance, the CAP remains a policy of strategic importance to ensure the most effective response to the policy challenges. European Union is not homogenous in terms of natural conditions. Here are any materials that carried out different possibilities for the delimitation of regions. The administrative delimitation in the EU is done using NUTS (EC, 2011) system; the rural point of view is included for example in Perlín (2010). The CAP after 2013 will be partly based on regional differences, on regional point of view. These regions are specified using natural conditions and this delimitation is also possible starting point to support these regions and areas with some specific payment (the current CAP supports from second Pillar for example less favoured areas). How different EU regions are from the point of selected agricultural indicators? Is possible to classify those regions? Which regions are similar, which are different across the EU? What is the position of the Czech Republic's regions?

Preparation of the CAP 2014+ is a long term process on which participate many institutions and organizations with different interests. Farmers are willing to farm in less favoured areas, in mountain areas but not without support. European Parliament (2010) also calls for the continuation of specific measures to compensate farmers producing in disadvantaged areas such as areas with natural handicaps, including mountainous regions, environmentally sensitive areas and/or regions which are the most affected by climate change, and outermost regions, in order to ensure that agricultural activity takes place so that land continues to be managed and local food is produced across the EU, reducing the threat of land abandonment and ensuring balanced territorial management across the EU and a rational development of agricultural production. Also Adinolfi, Little, Massot (2010) stress the need balanced territorial development. Supports for farms located in LFAs in the Proposal of the Regulation for next EU programming 
period (EC, 2011) belong to measures which are particularly important for increasing the competitiveness of all types of farming and improving the viability of farms. Concerning the balanced territorial development objective, the communication does not mention that relevant measures related to quality of life in rural areas or to territorial cohesion lie outside the scope of the CAP.

The need to evaluate territorial differences in light of natural conditions describes also EC (2006). They advert to costal and maritime basin zones on one the side and mountain areas on the other side. Sustainable EU of diverse differences is also embodied in EC (2011).

The source of data for all evaluations is the database General and Regional Statistics Eurostat 2007. The analysis included NUTS 2 regions across the EU, except those, which are formed as a city only. This is Brussels, Prague, Berlin, Bremen, Hamburg, Vienna, and Inner London. The overseas region of France and the autonomous region of Spain were also not evaluated.

Evaluation is done by using statistical methods for classification of regions and by using differences testing of selected indicators. Statistical analyses were processed in the SAS program.

Natural condition assessment is based on LFA indicators, such as agricultural land acreage of LFA in the proportion of the total region and the share of agricultural land in a mountainous area in the overall region. These indicators may be generally considered as those, which indicate worse or better natural condition.

Among groups of regions is assessed also economic situation based on standard economic indicators, namely HDP, unemployment, share of largest farms, proportion of economically active people in agricultural sector or average farm size.

\section{Cluster analysis}

In order to identify similarities and differences among regions with regard to natural conditions, it appears to be appropriate to use multivariate statistical analysis, especially cluster analysis.

Cluster analysis is one of the multivariate statistical methods used to classify objects (Hebák, 2005). It is used for sorting the units into groups (clusters) so that the units belonging to the same group are more similar to each other than objects from different groups. Cluster analysis can be performed both on: 1) the set of objects (in our case regions), each of which must be described by using the same set of variables - which are reasonable to track in this set of variables and 2) the set of variables which are characterized by a set of objects (regions). The ability to track similarities between variables was used in this work. Basic classification of methods of cluster analysis is hierarchical and non-hierarchical (Johnson, Wichern, 2007; Manly, 2005). When examining the nature of the examined similarities between variables, when the number of clusters is not known in advance, hierarchical methods are preferable due to branching classification. The most appropriate approach from hierarchical methods seems to be the "agglomerative approach". It is based on knowledge of variables, which are gradually connected to each other, respectively to generated clusters, until one cluster connecting a cluster of variables is created.

For the method of distance between metric variables was chosen a simple metric of Euclidean distance. Algorithm of linking was based on Ward's method, which is based on the least square method. Hierarchical clustering was used to determine the indicative number of clusters. It is due to usage of the database NUTS 2 regions, which contains more than 250 of them.

The assessment consisted of visual evaluation of the dendrogram with regard to knowledge of natural conditions in terms of LFA in the EU (Kučera, Štolbová, 2010; Štolbová, 2009). The approximate number of clusters resulting from the hierarchical method is a criterion for nonhierarchical method to k-means. It enabled the regions observed to split into a predetermined number of clusters. Quality criterion was to minimize the distribution of intra-regional variability.

Cluster analysis was performed on standardized values. Regions have been grouped according to natural conditions, which were represented by two indicators. First indicator is the percentage of agricultural land of LFA in the overall agricultural land of the region and the second indicator 
is the percentage of agricultural land of the mountainous area in the overall agricultural land in given region.

\section{Analysis of Variance}

Furthermore, in terms of selected indicators, differences between created clusters of regions were evaluated. Differences were tested in terms of the following indicators:

- GDP per capita (in EUR),

- proportion of economically active population employed in agriculture to all economically active persons in \%,

- unemployment rate in \%,

- proportion of farms with more than 100 ha of agricultural land in the number of all farms.

Testing was performed for each parameter separately by using a one-way analysis of variance (ANOVA). This is a multi-sampled test when differences in more than two groups of units are tested, in our case, clusters of regions. Method of one-way analysis of variance is based on the distribution of total variance on the dispersion between classes, which is related to the indicator (indicators are listed above) and the residual variance, which represents the rest of the influences on fluctuations of the values (Lapin, 1987).

The null hypothesis that among the selected groups there is no difference in the average value of the given indicator is tested. To verify the rejection or acceptation of the null hypothesis, the F-test is used. Decisions are made by comparing the maximum first type error (the $p$-value), based on our data, and errors of the first type of alpha, which we have set before testing. Alfa is usually set at $5 \%$. If the $p$-value is less than $5 \%$ alpha, the null hypothesis is rejected and it shows that there is a significant difference in the average value of the indicators in between monitored groups. Otherwise, the null hypothesis cannot be rejected and thus it is consider as valid.

In case of rejection of the null hypothesis further detailed evaluation is carried out. Alternative hypothesis applies. It can be formulated as follows: there is no significant difference in at least one pair of compared averages. We are not able to identify in which pair the difference exists and in which one it does not. For a more detailed evaluation many different methods are used, of which some of them are universal, other are not. Versatility of the methods allows even application for comparison of groups, which contain different number of statistical units, which are presented in our case as regions. The Scheffe's method used in the paper also belongs to the group of methods with detail evaluation.

\section{Results and Discussion}

Firstly, we divided the NUTS 2 EU regions into groups. The number of groups was not determined in advance, however, it was based on the fact that the number approximates limits of natural conditions, e.g. mountainous area and areas favorable for agriculture, and then areas representing the transition between them. Therefore, we considered three or four areas. Grouping was performed by using the cluster analysis based on standardized indicators of agricultural land acreage of LFA and the share of agricultural land in a mountainous area, both in the proportion of the of the total region area. 


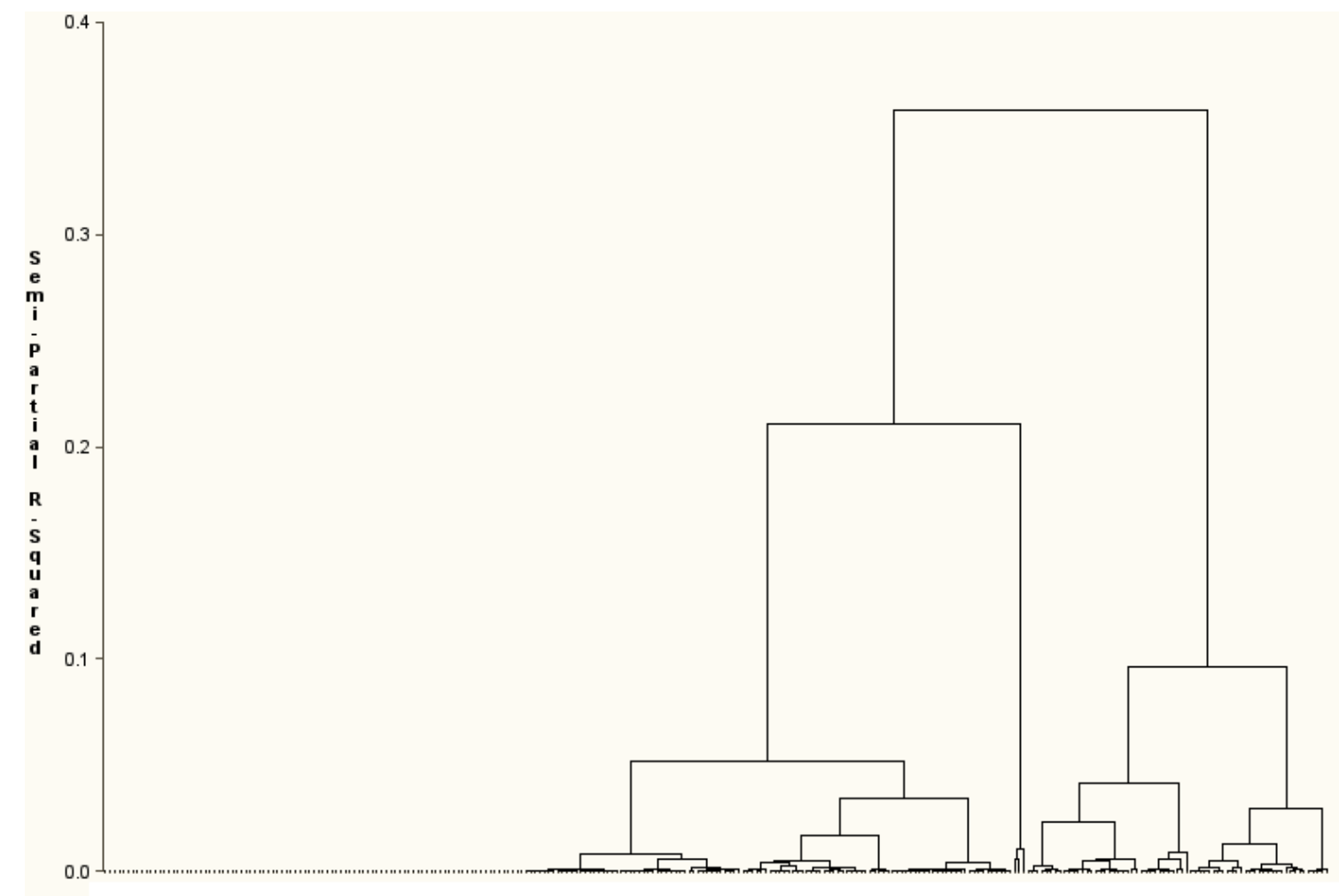

Name of Observation or Cluster

Fig 1. Dendrogram of NUTS 2 regions. Source: own processing.

Due to the large set of units, including more than 250 regions, the data was first examined by using hierarchical clustering techniques. For this purpose, we applied simple connection and metric distances based on Ward's method. The results are shown in the dendrogram (Figure No. 1). On the axis "y" is plotted the distance and on the axis "x" are displayed individual NUTS 2 regions. Their names are not displayed due to their high number and poor distinguishing ability. Nevertheless, important information is covered in the dendrogram. For the survey is important how the clusters of branches are divided. The axis " $y$ " is the distance between clusters. It holds that the greater the distance (longer line segment "branches"), the deeper disparity between the clusters. At the level of $R^{2}$ at the distance around 0.35 (axis " $y ")$, there are two clusters joined together. With further decreasing of $R^{2}$, they keep branching. In terms of branching, where the clusters are remarkably separated, the four groups of regions seem to be an appropriate number. This is in accordance with an objectively logical division, where there are considered to be three to four basic groups.

After the initial examination of the hierarchical method, the regions were segmented into four groups using non-hierarchical methods of K-means. This method is particularly suitable when we need to classify some larger number of units. Individual groups were identified as clusters (Cluster 1-4). The result of segmentation is presented in Figure No. 2. Cluster 1 represents regions with the most favourable natural conditions for farming; Cluster 4 includes the areas that are the least suitable for an intensive agricultural production. Clusters 2 and 3 are the transition between them. 


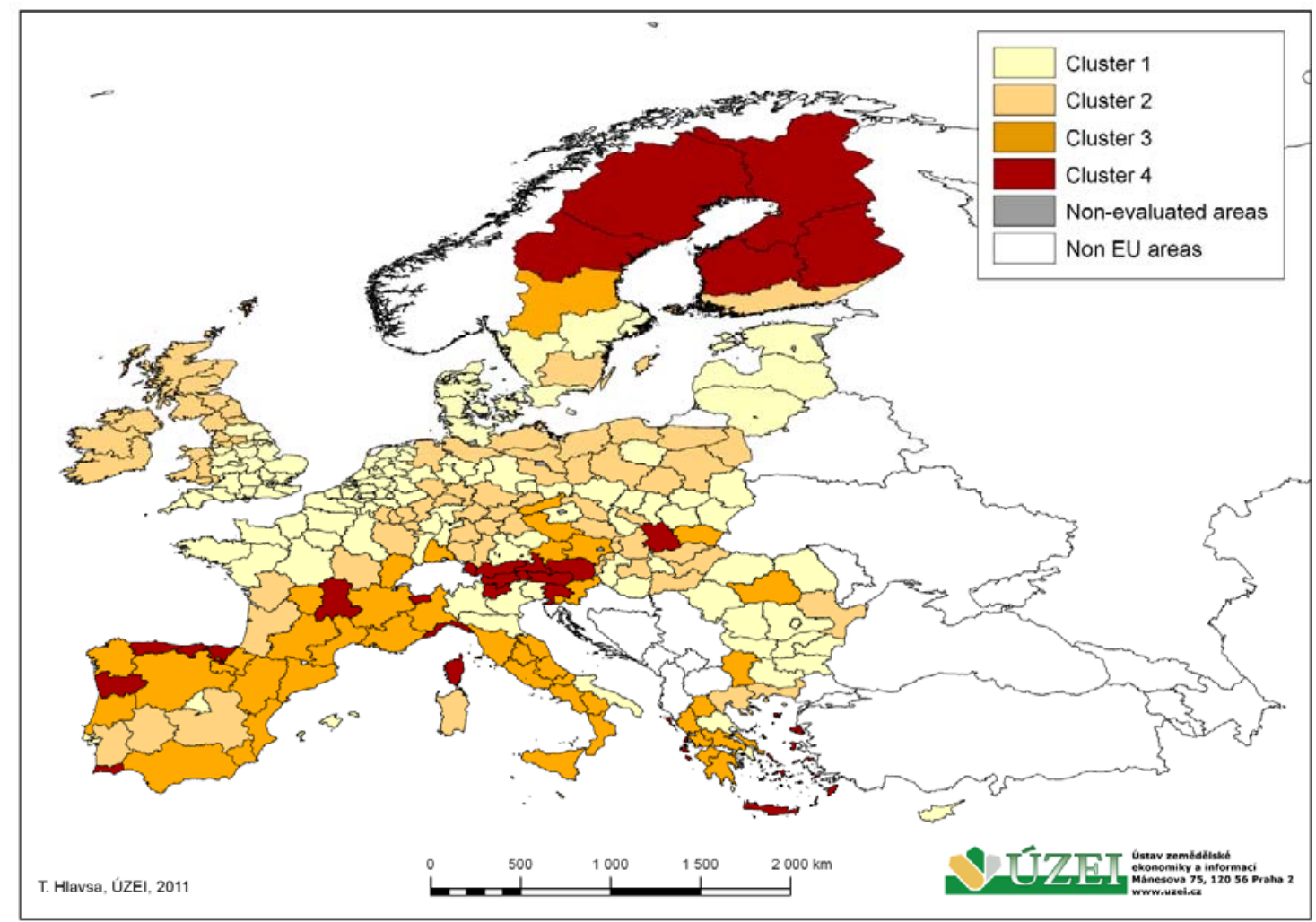

Fig 2. Groups of regions according to the clusters. Source: own processing.

Selected indicators of the agricultural production and economic performance of created cluster is shown in the table No. 1. The highest performance is visible in the first and fourth cluster, both as for economic performance measured by GDP and for agricultural crop production. The cluster No. 4 with worst conditions for intensive agriculture don't represent regions with the worst economic and production situation.

Cluster 1 represents regions showing favourable conditions for farming. The individual data obtained for this category are displayed in Table No. 1. This is mainly the area of the UK (South England), Benelux countries and coastal regions of France, Baltic States, Denmark, Romania's Danube region, southern Poland, Germany, Elbe and Rhine in Germany and Po Valley in Italy. Besides these, also Central Bohemia and Central Moravia are a part of this cluster. In general, these regions showed in terms of their natural conditions a low portion of agricultural land in the LFA and minimum in the mountainous area. The higher density of dairy cows, the low portion of permanent grasslands and the high portion of arable land characterized an average agriculture of these areas. The economic indicators of areas in this cluster were characterized by higher GDP and lower unemployment rate than in other regions of other clusters. Czech regions belonging to this cluster also showed on average three times bigger size of the farm than the EU average and the average of the Cluster 1. On the contrary, Polish, Bavarian, German and Romanian regions accounted for smaller ones.

\begin{tabular}{|c|c|c|c|c|c|}
\hline \multirow{2}{*}{$\begin{array}{c}\text { Cluster } \\
\text { No. }\end{array}$} & \multirow{2}{*}{$\begin{array}{l}\mathrm{Nr} \text {. of } \\
\text { regions }\end{array}$} & \multirow{2}{*}{$\begin{array}{l}\text { GDP per } \\
\text { capita }\end{array}$} & $\begin{array}{c}\text { Gross value } \\
\text { added }\end{array}$ & Animal output & Crop output \\
\hline & & & \multicolumn{3}{|c|}{ EUR per ha UAA } \\
\hline 1 & 116 & 24825 & 1567 & 1439 & 2167 \\
\hline 2 & 71 & 22718 & 785 & 1040 & 1016 \\
\hline 3 & 43 & 20926 & 1153 & 715 & 1423 \\
\hline 4 & 28 & 25136 & 1535 & 959 & 1736 \\
\hline
\end{tabular}

Tab 1. Source: Eurostat, 2007, own processing. 
Furthermore, the Czech regions were characterized by an apparently low proportion of dairy cows per hectare. Regarding permanent grasslands, the Czech regions in Cluster 1 showed below an average value compared to an average value of Cluster 1 . This is due to high greening of regions in this cluster that have no area in the LFA, such as the Netherlands and England. Arable land of Czech regions was on contrary above average, as in Denmark or Bulgaria.

\begin{tabular}{|c|c|c|c|c|c|}
\hline \multirow{2}{*}{ Variable } & \multirow{2}{*}{$\begin{array}{c}\begin{array}{c}\text { Czech } \\
\text { regions* } \\
\text { cluster no. } \\
1\end{array} \\
\text { average } \\
\end{array}$} & \multicolumn{3}{|c|}{ Cluster No. 1} & \multirow{2}{*}{$\begin{array}{c}\text { EU } \\
\text { average }\end{array}$} \\
\hline & & average & median & $\begin{array}{c}\text { var. coefficient } \\
(\%)\end{array}$ & \\
\hline \multicolumn{6}{|c|}{ Selected agricultural variables } \\
\hline $\begin{array}{l}\text { The proportion of farms with } \\
\text { acreage up to } 5 \text { ha a.l. in the total } \\
\text { number of farms }(\%)\end{array}$ & 44,73 & 44,15 & 42,22 & 61,87 & 45,91 \\
\hline Number of dairy cows per ha a.I. & 0,10 & 0,23 & 0,14 & 105,14 & 0,18 \\
\hline $\begin{array}{l}\text { Proportion of farms aimed at } \\
\text { permanent crops in the total } \\
\text { number of farms (\%) }\end{array}$ & 5,18 & 8,91 & 2,56 & 177,04 & 15,89 \\
\hline $\begin{array}{l}\text { Proportion of farms focused on } \\
\text { grazing cattle in the total number } \\
\text { of farms }(\%)\end{array}$ & 30,14 & 28,66 & 26,53 & 63,01 & 30,84 \\
\hline $\begin{array}{l}\text { The proportion of mixed aimed } \\
\text { farms in the total number of farms } \\
(\%)\end{array}$ & 13,11 & 10,79 & 10,57 & 66,95 & 9,89 \\
\hline $\begin{array}{l}\text { The average size of the farm in } \\
\text { hectares a.l. }\end{array}$ & 101,35 & 36,54 & 30,88 & 92,91 & 36,39 \\
\hline $\begin{array}{l}\text { Proportion of farms farming at the } \\
\text { permanent grasslands in the total } \\
\text { number of farms }(\%)\end{array}$ & 64,62 & 56,16 & 63,01 & 48,28 & 52,40 \\
\hline $\begin{array}{l}\text { The share of permanent crops on } \\
\text { a.l. }(\%)^{\star *}\end{array}$ & 0,09 & 1,40 & 0,00 & 345,89 & 2,85 \\
\hline $\begin{array}{l}\text { Share of permanent grassland in } \\
\text { the acreage of a.l. }(\%)\end{array}$ & 19,82 & 25,31 & 21,09 & 66,32 & 33,34 \\
\hline $\begin{array}{l}\text { Share of a.I. in LFA in the total } \\
\text { area of a.I. }(\%)\end{array}$ & 35,24 & 15,60 & 12,72 & 98,66 & 47,40 \\
\hline $\begin{array}{l}\text { Share of a.I. in the mountains (M) } \\
\text { in the total area of a.I. }(\%)\end{array}$ & 10,10 & 3,19 & 0,00 & 218,10 & 18,29 \\
\hline Arableland (\%) & 79,58 & 70,04 & 71,67 & 25,09 & 58,94 \\
\hline \multicolumn{6}{|c|}{ Selected economic variables } \\
\hline GDP (per capita) & 10600 & 24825 & 27250 & 46,55 & 23629 \\
\hline $\begin{array}{l}\text { The proportion of economically } \\
\text { active in agriculture in the total } \\
\text { number of economically active (\%) }\end{array}$ & 3,90 & 5,69 & 2,63 & 150,37 & 6,20 \\
\hline $\begin{array}{l}\text { The proportion of farms with } \\
\text { acreage of } 100 \text { ha a.l. in the total } \\
\text { number of farms }(\%)\end{array}$ & 12,30 & 8,73 & 6,57 & 110,33 & 7,54 \\
\hline
\end{tabular}

Tab 2. Coefficient of variation - cluster No. 1

Source: Eurostat, 2007, own processing

*) NUTS 2 regions of Central Bohemia and Moravia Central

$\left.{ }^{* *}\right)$ Includes the area under vines and olive trees

a.I. = agricultural land 
Unemployment rate in Czech regions was roughly half of the average of EU; and GDP was at around $40 \%$ of Cluster 1 . The EU-15 countries drove the economic level in the original cluster, in particular regions of the Netherlands, Denmark, Great Britain and France.

Looking closely at the variability of the values of individual indicators, which are represented by the coefficient of variation (Table No. 2), we can make following statements:

(i) very high variability (approximately $177 \%$ ) in the share of farms aimed at permanent crops. This is due to a very high proportion of them in regions with vineyards, mainly in Germany or France.

(ii) very high variability (approx. 218\%) is recorded at the proportion of mountainous areas on agricultural land. This is the case of areas more favourable for agriculture, but even such large regions, such as NUTS 2, contain partly the mountainous area of LFA, which affect this indicator. However, this is just a marginal area within certain NUTS 2.

Cluster 2 in comparison with the Cluster 1 already includes regions with specific natural handicaps and represents a natural transition from more to less favourable conditions. These are particularly the western regions of Slovakia, southern and northeastern Germany, central France, whole Ireland, Scotland, central Spain, northern Poland and Hungary and Czech eastern regions of Northeast and Southeast. Cluster 2 was characterized by a lower proportion of small farms less than 5 hectares of farmland. The farm specialization of more than average of these farms was in cattle grazing. There was also an above-average share of large farms and a low proportion of economically active population in agriculture.

In the case of Czech regions from this cluster, the average proportion of farms smaller than 5 hectares of farmland was higher than the EU average and the cluster's itself. However, similarly as in Cluster 1 , even here there were companies with greater size than the average cluster level (together with Brandenburg and Mecklenburg in Germany). Small farms in this cluster are typical for selected regions of Germany (Koblenz, Trier), Greece, Hungary, Poland, and Malta. Although Czech regions were characterized by approximately $50 \%$ of the acreage of agricultural land in LFA and a particularly high proportion of agricultural land in the mountainous area, the proportion of permanent grassland in comparison with the $\mathrm{EU}$ and the regions in the cluster itself was lower. Regions with higher shares of permanent grassland are located in Ireland, Portugal and France. On the contrary, low values were found in regions such as Hungary and Poland. In comparison to the average of Cluster 2, Czech regions showed about half of the economically active in agriculture as well as the level of GDP. A high proportion of employed in agriculture can be traced in the regions of Greece and Poland. Some more positive value of Czech regions compared with the cluster average could be seen in the unemployment rate. There still persist differences between regions of the original EU-15 and the new member states that joined in 2004 and later.

The variability of indicators across regions in Cluster 2 , which is measured by the coefficient of variation (Table No. 3), revealed the interesting results. Higher values of indicators suggested greater differences between regions. It was apparent that the variability in all parameters is relatively high, always exceeding $50 \%$. The share of farms aimed at permanent crops showed the highest values of fluctuation. On one hand, there are regions of Portugal, Spain, Italy, where the proportion of these farms reached up to $50 \%$ or more, and on the other hand, the regions with a low share such as regions of Ireland, Germany or Great Britain. Values for Czech regions exceeded the average of the cluster and they were comparable to the EU average, but the share of agricultural land on which permanent crops are grown remained relatively low $(0,61 \%)$. Most of the agricultural land was arable; the value for Czech regions located in this cluster is approximately $72 \%$, which was roughly 1.2 times more than the average of the cluster and the EU average.

The transition from less to more favourable conditions for intensive agriculture is represented by Cluster 3. Even in these areas, regions with some higher proportion of farms specialized in permanent intensive crops, such as vineyards (example of Provence and Lower Austria) are present. As shown in Table No. 3, generally it holds that the lower proportion of dairy cows, the higher share of permanent crops, the above-average proportion of agricultural land in 
the LFA, and also the above-average proportion of permanent grasslands. These distinguished Cluster 3 from the EU average. There was also an apparently lower value of GDP and higher unemployment rate in comparison with other clusters. The regions identified by these characteristics were among others areas such as central Italy, Lower and Upper Austria and southwestern part of Greece. Czech regions of this cluster are present in Southwest and Northwest. There was obviously some lower proportion of small farms less than 5 hectares of farmland, but there was some high proportion of farms with acreage of 100 hectares of farmland. This corresponded to the high average size of the enterprise which was roughly five times higher than the average of the cluster.

\begin{tabular}{|c|c|c|c|c|c|}
\hline \multirow{2}{*}{ Variable } & $\begin{array}{l}\text { Czech } \\
\text { regions* } \\
\text { cluster }\end{array}$ & \multicolumn{3}{|c|}{ Cluster No. 2} & \multirow{2}{*}{$\begin{array}{c}\text { EU } \\
\text { average }\end{array}$} \\
\hline & average & average & median & $\begin{array}{c}\text { var. coefficient } \\
(\%)\end{array}$ & \\
\hline \multicolumn{6}{|c|}{ Selected agricultural variables } \\
\hline $\begin{array}{l}\text { The proportion of farms with acreage } \\
\text { up to } 5 \text { ha of a.l. in the total number of } \\
\text { farms }(\%)\end{array}$ & 55,44 & 39,62 & 36,21 & 63,44 & 45,91 \\
\hline Number of dairy cows per ha a.l. & 0,13 & 0,18 & 0,14 & 87,85 & 0,18 \\
\hline $\begin{array}{l}\text { Proportion of farms aimed at } \\
\text { permanent crops in the total number } \\
\text { of farms }(\%)\end{array}$ & 14,75 & 11,99 & 4,72 & 132,42 & 15,89 \\
\hline $\begin{array}{l}\text { Proportion of farms focused on } \\
\text { grazing cattle in the total number of } \\
\text { farms (\%) }\end{array}$ & 27,87 & 35,90 & 36,68 & 65,20 & 30,84 \\
\hline $\begin{array}{l}\text { The proportion of mixed aimed farms } \\
\text { in the total number of farms }(\%)\end{array}$ & 14,35 & 11,54 & 11,78 & 63,46 & 9,89 \\
\hline The average farm size in hectares a.l. & 74,32 & 50,95 & 33,05 & 108,51 & 36,39 \\
\hline $\begin{array}{l}\text { Proportion of farms farming on the } \\
\text { permanent grassland in the total } \\
\text { number of farms }(\%)\end{array}$ & 64,76 & 57,53 & 64,75 & 57,70 & 52,40 \\
\hline $\begin{array}{l}\text { The share of permanent crops on a.l. } \\
(\%)^{\star *}\end{array}$ & 0,61 & 1,39 & 0,00 & 199,05 & 2,85 \\
\hline $\begin{array}{l}\text { Share of permanent grassland in the } \\
\text { acreage of a.l. }(\%)\end{array}$ & 27,82 & 34,34 & 26,22 & 83,48 & 33,34 \\
\hline $\begin{array}{l}\text { Share of a.l. in LFA in the total area of } \\
\text { a.I. }(\%)\end{array}$ & 51,91 & 67,88 & 64,29 & 26,52 & 47,40 \\
\hline $\begin{array}{l}\text { Share of a.l. in the mountains }(M) \text { in } \\
\text { the total area of a.l. }(\%)\end{array}$ & 16,76 & 2,84 & 0,00 & 212,97 & 18,29 \\
\hline Arable land (\%) & 71,35 & 57,98 & 64,87 & 42,58 & 58,94 \\
\hline & ed econo & nic variab & les & & \\
\hline GDP (per capita) & 10500 & 22718 & 24000 & 53,45 & 23629 \\
\hline $\begin{array}{l}\text { The proportion of economically } \\
\text { active in agriculture in the total } \\
\text { number of economically active (\%) }\end{array}$ & 3,93 & 5,83 & 4,04 & 101,16 & 6,20 \\
\hline $\begin{array}{l}\text { The proportion of farms with } \\
\text { acreage of } 100 \text { ha a.l. in the total } \\
\text { number of farms }(\%)\end{array}$ & 8,92 & 9,88 & 5,58 & 117,05 & 7,54 \\
\hline
\end{tabular}

Tab 3. Coefficient of variation - cluster No. 2

Source: Eurostat, 2007, own processing

*) NUTS 2 regions of Central Bohemia and Moravia Central

${ }^{* *}$ ) Includes the area under vines and olive trees 


\begin{tabular}{|c|c|c|c|c|c|}
\hline \multirow{2}{*}{ Variable } & \multirow{2}{*}{$\begin{array}{c}\begin{array}{c}\text { Czech } \\
\text { regions* } \\
\text { cluster no. } \\
3\end{array} \\
\\
\text { average }\end{array}$} & \multicolumn{3}{|c|}{ Cluster No. 3} & \multirow{2}{*}{$\begin{array}{c}\text { EU } \\
\text { average }\end{array}$} \\
\hline & & average & median & $\begin{array}{c}\text { var. coefficient } \\
(\%)\end{array}$ & \\
\hline \multicolumn{6}{|c|}{ Selected agricultural variables } \\
\hline $\begin{array}{l}\text { The proportion of farms with } \\
\text { acreage up to } 5 \text { ha of a.l. in the } \\
\text { total number of farms (\%) }\end{array}$ & 33,58 & 56,87 & 60,32 & 42,30 & 45,91 \\
\hline Number of dairy cows per ha a.l. & 0,08 & 0,10 & 0,05 & 115,13 & 0,18 \\
\hline $\begin{array}{l}\text { Proportion of farms aimed at } \\
\text { permanent crops in the total } \\
\text { number of farms }(\%)\end{array}$ & 3,80 & 34,44 & 33,49 & 76,21 & 15,89 \\
\hline $\begin{array}{l}\text { Proportion of farms focused on } \\
\text { grazing cattle in the total number } \\
\text { of farms }(\%)\end{array}$ & 36,69 & 20,56 & 11,90 & 93,31 & 30,84 \\
\hline $\begin{array}{l}\text { The proportion of mixed aimed } \\
\text { farms in the total number of farms } \\
(\%)\end{array}$ & 13,68 & 7,09 & 5,89 & 78,77 & 9,89 \\
\hline $\begin{array}{l}\text { The average farm size in hectares } \\
\text { a.l. }\end{array}$ & 125,26 & 23,29 & 10,22 & 122,20 & 36,39 \\
\hline $\begin{array}{l}\text { Proportion of farms farming on the } \\
\text { permanent grassland in the total } \\
\text { number of farms }(\%)\end{array}$ & 71,29 & 35,74 & 26,05 & 79,87 & 52,40 \\
\hline $\begin{array}{l}\text { The share of permanent crops on } \\
\text { a.l. }(\%)^{* *}\end{array}$ & 0,05 & 7,89 & 3,74 & 116,23 & 2,85 \\
\hline $\begin{array}{l}\text { Share of permanent grassland in } \\
\text { the acreage of a.I. }(\%)\end{array}$ & 36,79 & 35,99 & 36,28 & 60,28 & 33,34 \\
\hline $\begin{array}{l}\text { Share of a.I. in LFA in the total } \\
\text { area of a.I. }(\%)\end{array}$ & 70,37 & 69,40 & 68,86 & 24,77 & 47,40 \\
\hline $\begin{array}{l}\text { Share of a.I. in the mountains (M) } \\
\text { in the total area of a.I. (\%) }\end{array}$ & 26,86 & 40,19 & 39,89 & 24,76 & 18,29 \\
\hline Arable land (\%) & 62,90 & 48,71 & 46,15 & 35,75 & 58,94 \\
\hline \multicolumn{6}{|c|}{ Selected economic variables } \\
\hline GDP (per capita) & 10200 & 20926 & 21300 & 34,13 & 23629 \\
\hline $\begin{array}{l}\text { The proportion of economically } \\
\text { active in agriculture in the total } \\
\text { number of economically active (\%) }\end{array}$ & 4,10 & 7,81 & 5,35 & 83,24 & 6,20 \\
\hline $\begin{array}{l}\text { The proportion of farms with } \\
\text { acreage of } 100 \text { ha a.l. in the total } \\
\text { number of farms }(\%)\end{array}$ & 17,70 & 4,38 & 1,20 & 146,78 & 7,54 \\
\hline
\end{tabular}

Tab 4. Coefficient of variation - cluster No. 3

Source: Eurostat, 2007, own processing

*) NUTS 2 regions of Central Bohemia and Moravia Central

$\left.{ }^{* *}\right)$ Includes the area under vines and olive trees

Firms with smaller size represented the cluster, as being evident from the median, which was lower than average. Small farms are primarily located in regions of southern Europe. Czech regions showed a high proportion of agricultural land in LFA, about $70 \%$, which roughly corresponded to the average of the cluster and the EU. Also arable land in Czech regions showed with regard to the proportion of LFA relatively high values, at around $63 \%$, that exceeded the average of the cluster by $30 \%$. High values of this indicator were reported in the case of regions of Spain and Italy. On the contrary, low share of arable land was typical for regions of France. Czech economic performance of the regions located in this cluster, 
measured by GDP was roughly $50 \%$ of the cluster average level. Similarly, as in the case of the other clusters, the economic level was higher in regions of the original EU-15 comparing to newly accessing countries.

Of a high variability (see coefficient of variation, Table No. 4) was the indicator of the average business area at Cluster 3. High values are evident especially in Czech regions, as well as in selected areas of France (Auvergne, Corsica, Limousin, Franche-Comté). Low values of the area were recorded in the states of southern Europe. The high variability was also apparent in the density of dairy cows, where the Northeast and Northwest regions with the 0.08 of cows per hectares of agricultural land indicated the average position comparing to the average of the given cluster. In comparison with the EU average, it was below an average condition. The highest densities of dairy cows could be seen in French regions (Franche-Comté and Piemont), and furthermore in the regions of Italy (Lazio, Campania) and Germany (Freiburg).

\begin{tabular}{|c|c|c|c|c|}
\hline \multirow{3}{*}{ Variable } & \multicolumn{3}{|c|}{ Cluster No. 4} & \multirow{3}{*}{$\begin{array}{c}\text { EU } \\
\text { average }\end{array}$} \\
\hline & & & & \\
\hline & average & median & var. coefficient (\%) & \\
\hline \multicolumn{5}{|c|}{ Selected agricultural variables } \\
\hline $\begin{array}{l}\text { The proportion of farms with acreage } \\
\text { up to } 5 \text { ha a.I. in the total number of } \\
\text { farms }(\%)\end{array}$ & 52,23 & 54,52 & 55,78 & 45,91 \\
\hline Number of dairy cows per ha a.l. & 0,15 & 0,15 & 66,00 & 0,18 \\
\hline $\begin{array}{l}\text { Proportion of farms aimed at permanent } \\
\text { crops in the total number of farms }(\%)\end{array}$ & 23,38 & 12,54 & 115,72 & 15,89 \\
\hline $\begin{array}{l}\text { Proportion of farms focused on cattle } \\
\text { grazing in the total number of farms (\%) }\end{array}$ & 42,79 & 42,55 & 72,05 & 30,84 \\
\hline $\begin{array}{l}\text { The proportion of mixed aimed farms in } \\
\text { the total number of farms (\%) }\end{array}$ & 6,38 & 5,92 & 71,00 & 9,89 \\
\hline The average farm size in hectares a.l. & 18,93 & 15,16 & 83,85 & 36,39 \\
\hline $\begin{array}{l}\text { Proportion of farms farming permanent } \\
\text { grassland in the total number of farms } \\
(\%)\end{array}$ & 54,49 & 52,93 & 66,93 & 52,40 \\
\hline $\begin{array}{l}\text { The share of permanent crops on a.l. } \\
(\%)^{*}\end{array}$ & 4,67 & 0,87 & 177,91 & 2,85 \\
\hline $\begin{array}{l}\text { Share on permanent grassland acreage } \\
\text { in a.l. (\%) }\end{array}$ & 63,19 & 65,04 & 73,35 & 33,34 \\
\hline $\begin{array}{l}\text { Share oga.I. in LFA in the total area of } \\
\text { a.I. (\%) }\end{array}$ & 93,45 & 95,81 & 8,07 & 47,40 \\
\hline $\begin{array}{l}\text { Share of a.l. in the mountains }(\mathrm{M}) \text { in the } \\
\text { total area of a.I. }(\%)\end{array}$ & 83,61 & 87,65 & 17,07 & 18,29 \\
\hline Arable land (\%) & 31,06 & 21,37 & 107,46 & 58,94 \\
\hline \multicolumn{5}{|c|}{ Selected economic variables } \\
\hline GDP (per capita) & 25136 & 26250 & 29,73 & 23629 \\
\hline $\begin{array}{l}\text { The proportion of economically active in } \\
\text { agriculture in the total number of } \\
\text { economically active }(\%)\end{array}$ & 6,74 & 5,71 & 62,57 & 6,20 \\
\hline $\begin{array}{l}\text { The proportion of farms with acreage of } \\
100 \text { ha a.l. in the total number of farms } \\
(\%)\end{array}$ & 3,64 & 2,33 & 151,39 & 7,54 \\
\hline
\end{tabular}

Tab 5. Coefficient of variation - cluster No. 4

Source: Eurostat, 2007, the actual processing

*) Includes the area of vineyards and olive trees 
Cluster 4 represents mountainous areas. These are mainly the areas of northern Sweden, Finland, as well as the Alps, the Pyrenees or the Western Carpathians (Central Slovakia). As shown in Table No. 5, there was some high proportion of grazing cattle, higher proportion of smaller farms, high proportion of permanent grassland on the agricultural land and the share agricultural land in the LFA. Czech regions are not present in this cluster. In comparison with the EU average, there was some higher proportion of farms specialized in production of permanent crops. This was mainly due to location of regions with a focus on olive plantations and vineyards in Greece and in Italy. Because of significant inter-regional differences in this indicator, there was also a high coefficient of variation (Table No. 5), that was used to measure the variability of values. The average size of farms in the cluster corresponded to a small farm. In many cases, large-scale management did not mark the area, which was typical for the Czech Republic, the former GDR or the regions of favourable production conditions in Great Britain.

Despite the fact of production favorability, these regions lacked in their economic performance. This accounted for the values of GDP that is above the EU average and also the proportion of people employed in agriculture that exceeded the EU average. It was evident that in addition to production and maintenance of the countryside, agriculture was relatively significant social element. The farms were usually small that in many cases enabled to employ farmers. This fact may contribute to the continuation of farming in these areas and may help to avoid the land abandonment.

Very high variability was evident in the structure and the size of farms. The indicator share of farms with more than 100 hectares of farmland was quite different. This was the results of significantly higher values that were recorded in the region of Corsica (France). The primary focus of this area was on the extensive farming, and showed zero state of dairy cows. Low values were recorded in the Greek regions of the cluster and western Slovenia. The highest variability could be seen in the indicator share of permanent crops on agricultural land. Low values represented areas of western Austria, northern Finland and Sweden. On the contrary, a high proportion of permanent crops on agricultural land included for example the areas of Portugal (Algarve, Norte) and Greece (Crete).

\section{Testing differences between clusters of regions for selected indicators}

Among the formed clusters we further examined whether there are significant differences in selected indicators. Differences were tested on these variables:

- The shares in permanent grassland of a.l. (\%),

- $\quad$ Average size (ha of a. I.),

- The shares of largest farms (e.g., over 100 hectares of a.l.) to all farms (\%),

- GDP (per capita),

- The proportion of economically active in agricultural sector in all economically active $(\%)$,

- Unemployment rate $(\%)$.

Due to identified differences in mean values of individual indicators between the four clusters, we used the multi-sample test, namely the one-way analysis of variance (ANOVA).

For the monitored parameters the null hypothesis that there is no significant difference in mean values between the clusters was tested. The level of significance was tested at $5 \%$. If the $p-$ value is less than $5 \%(0.05)$, the null hypothesis of insignificance of differences is rejected. Then applies the alternative hypothesis which implies that at least in one pair of averages in compared clusters exist some difference. In this case, it needed some more detailed evaluation to determine the specific pair of different clusters. For this purpose, we used Scheffe's method. The results are shown in Table No. 6. As being shown, differences among certain clusters were present in indicators of land use and farm structure, while not proven in economic indicators. In the case of permanent grasslands' share of hectares on agricultural land, there were identified significant differences between the pairs of clusters 1 and 4, 2 and 4, 3 and 4. Cluster 4, which represents regions the least suitable for intensive farming, had a significantly higher proportion 
of permanent grassland than the other clusters. Clusters 1,2 and 3, where also Czech regions belong to, were not significantly different. Other significant differences were present in the average size of enterprises. The problem of farm business size as a barrier for future unification of CAP is also pointed out in the work of Tamáš (2010). The largest companies with an average area significantly different from the other enterprises in other clusters were located in regions of Cluster 2 . These are specifically the Northeast and Southeast regions. Between favorable conditions (Cluster 1 ) and regions that represent the transition from the favourable to worse conditions (Cluster 2) was not proven any significant difference in the average size of farms. The overall European trend of farm size development shows (Vošta, 2012), that from 2003 decrease proportion of small farms and increase proportion of bigger farms (more than $100 \mathrm{ESU})$. In our distribution in four clusters was observed indicator proportion of farms over 100 hectares of a.l. Again, the highest value observed was in Cluster 2 that represents regions with slightly worse conditions for farming. Significant differences were then observed in comparison with Cluster 3 and 4 . These were characterized by a low proportion of agricultural acreage farms over 100 hectares of a.l.

\begin{tabular}{|l|r|r|c|c|}
\hline \multicolumn{1}{|c|}{ Variance } & $\begin{array}{c}\text { Test criterion } \\
\text { F-test }\end{array}$ & P-value* $^{*}$ & $\begin{array}{c}\text { Inter-clusters } \\
\text { differences }\end{array}$ & $\begin{array}{c}\text { Different } \\
\text { clusters }^{* * *}\end{array}$ \\
\hline $\begin{array}{l}\text { The proportion of permanent grassland } \\
\text { to a.l. }\end{array}$ & 9,02 & $<0,001$ & YES & $1-4 ; 2-4 ; 3-4$ \\
\hline The average size & 6,37 & 0,0002 & YES & $2-3 ; 2-4$ \\
\hline Proportion of farms on 100 ha of a.l. & 4,92 & 0,0020 & YES & $2-3 ; 2-4$ \\
\hline GDP & 2,21 & 0,0793 & NO & $\mathrm{x}$ \\
\hline The share of EA in the agriculture & 0,76 & 0,4939 & NO & $\mathrm{x}$ \\
\hline The unemployment rate & 2,90 & 0,0635 & NO & $\mathrm{x}$ \\
\hline
\end{tabular}

Tab 6. Results of analysis of variance for selected indicators

Source: Eurostat, 2007, own processing

*) The probability of maximal first type error

$\left.{ }^{* *}\right)$ The differences were tested for significance level $\alpha=0.05$

$\left.{ }^{* *}\right)$ A more detailed evaluation of differences was performed by using the Scheffe's method

Statistically significant differences among clusters have not been detected in case of selected economic indicators. It means that differences in GDP and unemployment rate across clusters (areas) are not significant argument to distribute higher LFA payments to regions and areas with lower GDP, respectively higher unemployment rate. These findings are also with agreement with Shucksmith, Thomson and Roberts (2005).

The level of observed regions NUTS 2 hides information about differences at lower regional level, such as NUTS 3 or 4 . This is given due the larger size of NUTS 2 regions; in many cases are in the same region mountainous areas and areas with better conditions. This aspect of regional internal variability is also need to take in to account, because the NUTS 2 level represents than average situation.

\section{Conclusion}

The cluster analysis has enabled us to classify NUTS 2 EU regions into four groups according to their natural conditions. The first group represents favorable conditions for agriculture, the second one the unsuitable conditions for intensive agriculture - mountainous areas and last two groups represent a transition between them. Czech regions found to be located in all groups except Cluster 4 (mountainous regions).

Selected indicators of farm structure in regions, land use and indicators of economic regions were then used to survey the individual clusters. We can say that despite similar natural conditions within the cluster of regions, there are differences in farm structures, size of the enterprises, business specialization and economic indicators. Between the clusters of regions, there are not found any significant differences in economic indicators. On the contrary, 
indicators of land use and farm size reveal statistically significant differences in the proportion of permanent grassland, the proportion of farms with more than 100 hectares of agricultural land and the average size of enterprises.

Czech regions within their clusters differ from other regions, especially in the high value of the average size of farms, lower GDP, higher arability in the less-favored areas, and despite a higher proportion of agricultural land in LFA, also in terms of less grassing. Czech regions are characterized even in LFA in the European context by their low level of dairy cows and by larger companies, which cultivate mainly the arable land. Regional differences in land use and structure of companies in similar natural conditions are the results of the requirement to maintain farmers' incomes and their rational economic behavior. Large enterprises in Czech regions are present in all clusters, especially in Cluster 3. It represents the transition from worse economic conditions to the mountainous area. On average, there can be traced the largest enterprises and the highest proportion of companies specialized in grazing cattle. Grassing of agricultural land of Czech regions in favorable conditions (Cluster 1) and in the transition area (Cluster 2) is lower than the average of the cluster and the EU. An above average grassing of Czech regions (compared with the average of the cluster and the EU) is evident in Cluster 3. There are the largest Czech companies in terms of the acreage of agricultural land.

Expected capping of direct payments would have an impact on the largest enterprises in the economy, especially in transition areas. If the interest of the CAP or the national policy is to maintain the land management in these areas, it needs to continue with compensation for natural handicaps that are subject to present LFA payments, but it also needs to solve the limitations of direct payments based on the farm size (capping). Furthermore, natural conditions differences are not related to differences in economic indicators, it corresponds with conclusions of European Commission (EC, 2011). Production criteria, such as stock density or grassing, cannot be used for delimitation of LFA. High share of permanent grassland is also evident in areas suitable for intensive farming. The analysis at NUTS 2 level showed a rather rough overview than the analysis made at lower NUTS level. But the NUTS 2 view also helpful to get comprehensive information about the situation. This analysis might be used for policy makers as general overview of possible areas where could be paid bigger or special attention and may be then also elaborated at lower regional level.

References

[1] Adinolfi F., Little J. \& Massot A. (2010). The CAP towards 2020: Briefing note for European Parliament. Bruxelles: DirectorateGeneral for internal policies.

[2] Agriculture and Rural Development (2011). Proposal for a regulation of the European parliament and of the Council on support for rural development by the European Agricultural Fund for Rural Development (EAFRD). Bruxelles, European Commision, [retrieved 2012-03-31]. Available from: http://ec.europa.eu/agriculture/cap-post-2013/legalproposals/index_en.htm.

[3] Boháčková, I. \& Hrabánková, M. (2009). Strukturální politika Evropské unie. Praha: C. H. Beck, 2009.

[4] Baldock, D., Rayment, M., Kuhmonen, T., Terluin, I., Swales, V., Poux, X., Zakeossian, D. \& Farmer, M. (2006). An evaluation of the Less Favoured Area measure in the 25 member states of the European Union. London: Institute for European Environmental Policy London.

[5] Crabtree, R., et al. (2003). Review of Area - based Less Favoured Area Payments across Great Britain. Oxford: CJC Consulting.

[6] Crabtree, R., et al. (2003). Review of Area - based Less Favoured Area Payments across EU Member States.Oxford: CJC Consulting. 
[7] Towards a Stronger European Territorial Cohesion in the Light of the Lisbon and Gothenburg Ambitions (2006). Bruxelles, European Commission.

[8] European Parliament, Legislative Observatory (2010). [retrieved 2012-03-22]. Available from: http://www.europarl.europa.eu/oeil/popups/summary.do?id=1117600\&t=d\&l=en.

[9] Hebák, P., Hustopecký, J., Pecáková, I., Průša, M., Řezanková, H., Svobodová, A. \& Vlach, P. (2005). Vícerozměrné statistické metody 3. Praha: Informatorium.

[10] Johnson, R. A. \& Wichern, D. W. (2007). Applied Multivariate Statistical Analysis. $6^{\text {th }}$ ed., Upper Saddle River: Pearson.

[11] Kučera, J. \& Štolbová, M. (2010): Metodika aplikace společných kriterií EU pro redefinici LFA v podmínkách ČR. Praha: ÚZEI.

[12] Lapin, L. L. (1987). Statistics for modern business decisions. $4^{\text {th }}$ ed. San Diego: Harcourt.

[13] Manly, B. F. J. (2005). Multivariate statistical methods. Laramie: Chapman and Hall.

[14] Nomenclature of territorial units for statistics (2011). Bruxelles: European Commision/ Eurostat, [retrieved 2012-01-05]. Available from: http://epp.eurostat.ec.europa.eu/portal/page/portal/nuts_nomenclature/introduction.

[15] Perlín, R. (2010). Theoretical approaches of methods to delimitate rural and urban areas. European Countryside, 2(4), 182-200. Doi: 10.2478/v10091-010-0013-5.

[16] Regulation of the European Parliament and of the council on support for rural development by the EAFRD (2011). Bruxelles, European Commision.

[17] Shucksmith, M., Thomson, K. J. \& Roberts, D. (2005). CAP and the regions, the territorieal impact at the Common Agricultural Policy. Wallingford: CAB International.

[18] Štolbová, M. (2009). Metodika aplikace jemného doladění (fine tuning) nově stanovených LFA podle produkčních kriterií v podmínkách ČR. Praha: ÚZEI.

[19] Tamáš, V. (2010). Problem of the dual structure of farms in European transition economies. Acta univ. agric. et silvic. Mendel. Brun. 58(6), 571-578.

[20] Territorial Agenda of the European Union 2020 (2011). Bruxelles, European Commission.

[21] The future of the CAP after the 2013 (2011). Bruxelles: Copa\&Cogeca.

[22] Vošta, M. (2012). Agriculture under the conditions of globalisation. Agricultural economics 58(7), 165-171.

[23] Wilkin, J. (2003). The future of EU agricultural and rural policy from the perspective of CEE candidate countries (pp. 135-152). In Policy vision for sustainable rural economies in an enlarged Europe. Hannover: Akademie für Raumforschung und Landesplanung. 